\title{
O LUGAR DA ARTE EM TEMPOS DA COVID-19
}

Viviane Maria Candiotto

Gladir da Silva Cabral

\section{DOI: http://dx.doi.org/10.18616/intcov22}

A covid-19 é uma doença causada por um novo coronavírus que varia de quadros assintomáticos a quadros respiratórios de infecção grave com alta taxa de óbitos. Em pouco tempo, a Organização Mundial da Saúde (OMS) decretou esse cenário como de emergência de saúde pública internacional. Passados seis meses do surgimento da doença, já há alguns entendimentos sobre a velocidade do contágio de pessoa para pessoa e da necessidade de medidas de isolamento social.

Vive-se hoje uma realidade em que famílias passaram a se comunicar basicamente por meio de recursos tecnológicos e mídias sociais, com distanciamento, isso somado à higienização das mãos, uso de máscaras e restrições de eventos de grande porte, viagens e muitas contradições sobre a nova doença. Nesse contexto, é pertinente refletir sobre a arte como uma manifestação humana que nos acompanha e nos possibilita conhecer a vida. Assim, é importante pontuar como a arte pode ser utilizada para lidar com a crise humanitária, levando significado e resiliência para a vida das pessoas.

O caráter terapêutico da arte tem sido reconhecido e estudado amplamente ao longo da história, como aponta Alice Casanova dos Reis (2014) em seu artigo "A arte como dispositiva à recriação de si: uma prática em psicologia social baseada no fazer artístico". Sua pesquisa traz como referência autores da psicologia histórico-cultural, como Vigotski e Bakhtin. Segundo a autora, a arte pode ser uma grande aliada no cuidado da saúde psicológica e física do ser humano, afetando diretamente a qualidade de vida das pessoas. A arte estimula a criatividade, facilita a comunicação, a compreensão e significação da realidade bem como torna-se recurso vital para a construção de si.

É pela arte que a humanidade expressa suas carências, ideias, convicções, e nessa história coletiva do caos instalado por pandemias, é im- 
prescindível sensibilizar a humanidade para a solidariedade, a resiliência, a criatividade e a importância de uma mobilização mundial para combater a doença e preservar a saúde dos seres humanos. No artigo intitulado "Em ano de peste", Mike Davis (2020) lista várias obras de arte que anteciparam a chegada de um vírus mortal, como o livro The Hot Zone, de Richard Preston de 1994, o filme Contágio, de Steven Soderberg, lançado em 2011, além de filmes e romances lúgubres. Tais criações estéticas ajudam a construir um significado para a experiência pandêmica.

Nesses tempos em que a pandemia da covid-19 avança, que traz consigo a perda de milhares de pessoas, a arte se confirma como um recurso de enfrentamento, acolhida, solidariedade e sensibilidade, seja nos compartilhamentos diversos de canções, poemas, peças musicais, danças, quadros, artes digitais etc. A arte ajuda a ordenar o caos e a significar o mundo.

\section{REFERÊNCIAS}

DAVIS, Mike. Em ano de peste. Rev. Movimento: Crítica, Teoria e Ação. Movimento Esquerda Socialista, Porto Alegre, v. 1, n. 16, ano 5, p. 131139, jan./mar. 2020.

REIS, Alice Casanova. A arte como dispositivo à recriação de si: uma prática em psicologia social baseada no fazer artístico. Barbarói, Santa Cruz do Sul, n. 40, p. 246-63, 2014. Disponível em: https://online.unisc.br/seer/index.php/ barbaroi/article/viewFile/3386/3550. Acesso em: 21 jul. 2020. 